\title{
LAERE
}

MIDDEL ODK

\section{Teknologiforståelse for alle?}

- fagdidaktisk analyse af erhvervsuddannelsernes nye grundfag Erhvervsinformatik

Af Marianne Riis, Jens Jørgen Hansen \& Peter Holmboe

Korrekt citering af denne artikel efter APA-systemet (American Psychological Association System, 7th Edition):

Riis, M., Hansen, J. J. \& Holmboe, P. (2021). Teknologiforståelse for alle? - fagdidaktisk analyse af erhvervsuddannelsernes nye grundfag Erhvervsinformatik. Learning Tech - Tidsskrift for læremidler, didaktik og teknologi, (10), 351-381. DOI 10.7146/It.v6i10.125555 


\section{Abstract}

Erhvervsinformatik er et nyt grundfag, der er målrettet erhvervsskoleelevers behov for udvikling af teknologiforståelse. Forskning i erhvervsuddannelsers forståelse og anvendelse af (digital) teknologi er yderst sparsom i Danmark. Formålet med denne artikel er at undersøge undervisningsfaget Erhvervsinformatik i forhold til, hvordan faget tilgodeser erhvervsuddannelsernes særkende og de intentioner, der er med faget for på denne måde at bidrage med ny viden til feltet. Metodisk baserer artiklen sig på en fagdidaktisk analyse af fagets læreplaner, der er analyseret i forhold til fagets identitet, indhold og intenderede praksis. Gennem analyserne viser vi, at Erhvervsinformatik tager højde for erhvervsuddannelsernes særkende og lever op til de intentioner, der er med faget i denne kontekst, men vi finder også anledning til at problematisere en række forhold. Afslutningsvist peger vi på behov for yderligere empirisk forskning med henblik på at opnå en dybere forståelse af undervisningsfaget Erhvervsinformatik og måden, hvorpå det realiseres i praksis.

Vocational Informatics is a new subject area recently introduced in Danish Vocational Education and Training. In this article, we conduct a line-by-line analysis of central formal documents describing how the subject is intended, not performed. In the analyses, we focus on the subject's identity, content and intended practice. Overall, we find that the subject aligns well with the intentions of vocational education and training, but we also raise issues of concern e.g., the vocational teachers' knowledge and competences with regards to teaching this new subject. We conclude the article by pointing to new areas of research and development needed to transform the subject's intentions to actual practice in the vocational schools. 


\section{Teknologiforståelse for alle?}

\section{- fagdidaktisk analyse af erhvervsuddannelser- nes nye grundfag Erhvervsinformatik}

\section{Teknologiforståelse som ny faglighed for alle i uddannelsessystemet}

Formålet med denne artikel er at undersøge undervisningsfaget Erhvervsinformatiks identitet, indhold og intenderede praksis gennem en fagdidaktisk analyse. Erhvervsinformatik er et nyt grundfag i erhvervsuddannelserne, der har som formål at øge elevernes forståelse af (digital) teknologi og dermed klæde eleverne på til at kunne begå sig i et samfund og på et arbejdsmarked, der i stigende grad præges af digitalisering. Undervisning i, med og gennem digitale teknologier er ikke nyt i det danske uddannelsessystem, heller ikke på erhvervsuddannelserne, men gennem de senere år er fagfeltet blevet udvidet med henvisning til den nye faglighed teknologiforståelse. Følger man den offentlige debat om teknologiforståelse, kan man nemt få det indtryk, at det primært handler om udvikling af et nyt fag og en ny faglighed i grundskolen. Ikke desto mindre er teknologiforståelse tænkt som en faglighed, der kan blive gennemgående for hele uddannelsessystemet.

Den nationale kapacitetsgruppe for teknologiforståelse udarbejdede i 2020 en gap-analyse, der beskriver status på udvikling af teknologiforståelse i uddannelsessystemet og kommer med anbefalinger til det videre arbejde (Basballe, Caspersen, Hansen, Hjort, Iversen \& Kanstrup, 2021). Indledningsvist beskrives teknologiforståelse således i gap-analysen: 
9) Teknologiforståelse er på vej som ny faglighed i det danske uddannelsessystem. Både på videregående uddannelser, ungdomsuddannelser og i grundskolen forberedes og afprøves fag og faglighed. Tiltagene er forskellige, men har udgangspunkt i et mål om at etablere en fundamental teknologiforståelse, som til forskel fra en redskabsorienteret anvendelse af teknologi har et almendannende formål, hvor de kommende generationer lærer en dybere teknologiforståelse, der kan udmøntes i kreativ handlekraft om og med digital teknologi.

(Basballe, Caspersen, Hansen, Hjort, Iversen \& Kanstrup, 2021, S. 3)

Udvikling af teknologiforståelsesfagligheden har indtil videre været særligt udbredt i grundskolen og den tilhørende læreruddannelse, hvor der siden 2018 har pågået forskellige forsøg med udvikling af faget og fagligheden. På den baggrund bemærkes det også i gapanalysen, at "den nye faglighed i grundskolen udgør et afgørende udgangspunkt for udviklingen af hele det danske uddannelsessystem" (Basballe, Caspersen, Hansen, Hjort, Iversen \& Kanstrup, 2021, s. 3). Da der endnu ikke er publiceret forskning i Erhvervsinformatik, og der i $\emptyset$ vrigt er personsammenfald mellem dem, som har formuleret fagene i både grundskolen og på ungdomsuddannelserne, vil vi i vores analyse af Erhvervsinformatik også trække på viden om fagligheden fra disse uddannelser.

\section{Erhvervsinformatik - fra basisfag til undervisningsfag}

Undervisningsfaget Erhvervsinformatik begrundes ud fra en udfordringsdidaktisk position, hvor målet ifølge Nielsen (2004) er, at eleverne arbejder med komplekse, globale problemer (som for eksempel digitalisering) og på den baggrund udvikler bevidsthed, forståelse, myndighed og handlekompetence. Samtidig bærer faget præg af at være blevet skabt ud fra en basisfaglig didaktisk position, der blandt andet er karakteriseret ved, at "undervisningens indhold og ofte også dens form er baseret på de videnskaber, der er basis for fagene" (Krogh, Qvortrup \& Christensen, 2018, s. 52). I tilfældet Erhvervsinformatik drejer det sig om henholdsvis design, datalogi og informatik (Basballe, Caspersen, Hansen, Hjort, Iversen \& Kanstrup, 2021).

Undervisningsopgaven er imidlertid ikke blot at (videre-) 
formidle basisfag til eleverne, men derimod at omsætte og transformere basisfaglig viden til undervisningsfaglig viden. Dermed bliver det relevant at undersøge, hvorledes denne transformation er foregået i forhold til Erhvervsinformatik, og her kan en fagdidaktisk analyse bidrage til at skabe klarhed over fagets identitet, indhold og praksis.

Ifølge Hansen (2012, s. 226) knytter fagdidaktikkens funktion sig til "den opgave, som fagdidaktik varetager i forhold til de aktører, der undersøger, bruger eller udsættes for fagdidaktisk kundskab og beslutninger. Aktører kan både være forskere, politikere, undervisere, ledere, forældre og elever". Som Hansen ydermere påpeger, bruges fagdidaktik også af forskere til "at undersøge og kommunikere om væsentlige pædagogiske mål, indhold, metoder og aktiviteter" (Hansen, 2012, s. 226), hvilket også er tilfældet i denne artikel. Fagdidaktikken har på den ene side et praktisk sigte, som understøtter refleksion og handleorientering indenfor et bestemt fag og undervisningskontekst. På den anden side er fagdidaktik en særlig videnskab, jævnfør Jank \& Meyers (2012, s. 34) definition: "Fagdidaktikker er særlige videnskaber, der udfordrer og strukturer forudsætninger, muligheder, konsekvenser og grænser for læring og undervisning indenfor et fagligt felt i eller uden for skolemæssige sammenhænge". Vores hensigt er at bidrage til en fagdidaktik om grundfaget Erhvervsinformatik, og vi foretager derfor en fagdidaktisk analyse på grundlag af fagets læreplan ud fra følgende forskningsspørgsmål:

\section{Hvordan er identitet, indhold og intenderet praksis, som disse udtrykkes i læreplanen for grundfaget Erhvervsinfor- matik, tænkt i forhold til erhvervsuddannelsernes sær- kende og hensigten med at uddanne i den nye faglighed?}

I det følgende præsenteres først vores metodiske tilgang. Herefter beskriver vi kortfattet erhvervsuddannelsernes særkende, der har til formål at rammesætte de vilkår, som faget Erhvervsinformatik udvikles og udmøntes under. Dernæst følger tre delanalyser med fokus på netop fagets identitet, indhold og intenderede praksis. Resultaterne heraf diskuteres afslutningsvist med en opsamling og konklusion i forhold til ovennævnte forskningsspørgsmål. 


\section{Fagdidaktisk læreplansanalyse som metode}

Fagdidaktikken koncentrerer sig om undervisning og læring i fag og faglig kundskab og beskæftiger sig altid med de didaktiske grundspørgsmål ud fra et fagligt perspektiv (Krogh, Qvortrup \& Christensen, 2018). Lovgivning, bekendtgørelser og vejledninger hertil, der tilsammen udgør en skole eller uddannelses loereplan, sætter rammerne for organisering, og nok så vigtigt, hvilken viden, færdigheder, kompetencer og dannelsesmål undervisningen skal fokusere på, hvilket hermed rammesætter den didaktiske retning for undervisningsarbejdet. En fagdidaktisk læreplansanalyse kan derfor afdække, hvilke didaktiske intentioner, der måtte være med et givent undervisningsfag, i dette tilfælde Erhvervsinformatik.

\section{Læreplansfunktioner og -former}

En læreplan er en social konstruktion af, hvad et fag er, hvilke elementer faget består af, og hvordan man bør undervise i faget. En læreplan har således både en politisk funktion, en programmatisk funktion og en praktisk funktion (Hopmann, Künzli \& Jacobsen, 1995; Hansen, 2021).

Læreplanens politiske funktion afspejler, at et fags opståen er resultatet af en politisk kamp, hvor forskellige aktører har interesserer $\mathrm{i}$, at faget bliver en del af en uddannelses fagportefølje. Disse aktører vil argumentere for, at faget reflekter viden, som man samfundsmæssigt opfatter som validt og vigtigt (Cunningham \& Kelly, 2017). Læreplanen er dermed del af en generationskontrakt, det vil sige udtrykker en viden, som samfundet ønsker, at skolen skal overføre til nye generationer (Schleiermacher, 1826; Gundem, 1996; von Oettingen, 2016). Den programmatiske funktion viser sig ved, at læreplanen for en skole beskriver, hvordan man skal forstå og organisere et fag og kaster dermed lys over, hvad fagets mål og stofområder er. Den praktiske dimension handler om, at læreplanen er et arbejdsredskab og en vejledning til læreren om, hvordan de skal fortolke, didaktisere og udmønte faget i deres undervisning. Læreplaner er i den forstand a plan for learning (Taba, 1962). I teorier om læreplaner skelnes typisk mellem fem læreplansformer (Goodlad, Klein \& Tye, 1979; Imsen, 2013): 
— Den ideale læreplan

— Den formelle læreplan

— Den fortolkede læreplan

- Den realiserede læreplan

— Den erfarede læreplan

Den ideale loereplan omhandler det filosofiske grundlag og værdier for læreplanen. Den formelle loereplan er den læreplan, som er synlig som politisk dokument på undervisningsministeriets hjemmeside. Man kan også kalde denne læreplan for den intentionelle læreplan (Van den Akker, 2004). Den fortolkede loereplan afspejler, hvordan undervisere fortolker læreplanen i deres didaktiske arbejde på grundlag af deres undervisnings- og fagsyn. Den gennemførte loereplan handler om, hvordan undervisere udmønter læreplanen i en konkret skolepraksis. Den erfarede loereplan ser læreplanen ud fra elevens perspektiv: hvad har eleven lært i lyset af læreplanens mål og indhold.

De forskellige læreplansformer åbner også for forskellige forskningstilgange. Schubert (2008) peger på, at læreplaner kan undersøges med forskellige hensigter: for eksempel empirisk, hermeneutisk, kritisk og postmoderne. Vores tilgang er hermeneutisk, det vil sige, at vi undersøger læreplaner som tekst, som ifølge Schubert "can be any idea or event that is transformed by exchange of ideas over time" (2008, s. 401). Derfor er vores udgangspunktet også den formelle læreplan, hvor læreplanen fungerer som et politisk dokument. Hensigten er at forsøge at forstå og perspektivere læreplanen og dens ideologiske, didaktiske og metodiske intentioner.

\section{Forskning i læreplaner inden for feltet teknologiforståelse}

Der er tidligere foretaget forskning i en dansk skole- og uddannelseskontekst af læreplaner i forhold til det felt som benævnes forskelligt, men indholdsmæssigt har visse ligheder henholdsvis teknologiforståelse, computational thinking, informationsteknologi og informatik. Denne forskning har beskæftiget sig med forskellige aspekter af læreplansformer. Caspersen, Iversen, Nielsen, Hjort og Musaeus (2018) har i artiklen 'Computational Thinking - hvorfor, hvad og hvordan' udfoldet især den ideale læreplan og begrundelsen for fagfeltet computational thinking. Hansen (2021) har i artiklen 'Teknologiforståelsesdidaktik' analyseret 
folkeskolefaget Teknologiforståelse i lyset af den formelle læreplan. Petersen (2017) har i artiklen 'Potentiale og realiserbarhed i forsøgslæreplanen for Informationsteknologi C og B i gymnasiet' analyseret både den formelle og den realiserede læreplan. Endelig har en række forskere og undervisere i bogen 'Fra Kierkegaard til koder. Computational thinking i gymnasiet' (Lundstrøm, 2020) haft som mål at "udfolde og konkretisere, hvad CT i undervisningen egentlig er eller kan være" (Lundstrøm, 2020, s. 2), og undersøgelsen omfatter i det tilfælde både den fortolkede- og realiserede læreplan.

\section{Formel læreplansanalyse på tre niveauer}

Den videnskabelige fagdidaktik bidrager både med et analytisk og et normativt begrebsapparat, der kan kvalificere forskellige forhold omkring tilblivelse og udmøntning af undervisningsfag, som illustreret i Tabel 1 herunder.

\section{Tabel 1.}

Fagdidaktikkens genstandsområde (Hansen, 2012, s. 228).

\begin{tabular}{|c|c|c|c|}
\hline & \multicolumn{3}{|c|}{ Fagdidaktikkens genstandsområde } \\
\hline & Fagenes identitet & Fagenes indhold & Fagenes praksis \\
\hline $\begin{array}{l}\text { Fagenes beskrivelse } \\
\text { (didaktologi) }\end{array}$ & $\begin{array}{l}\text { Basisfag, kunst og } \\
\text { håndværk }\end{array}$ & $\begin{array}{l}\text { Mål, viden, } \\
\text { færdigheder og } \\
\text { kompetencer }\end{array}$ & $\begin{array}{l}\text { Fagets metoder, } \\
\text { aktivitetsformer, } \\
\text { organisation og } \\
\text { læremidler }\end{array}$ \\
\hline $\begin{array}{l}\text { Fagenes } \\
\text { værdisætning } \\
\text { (normativ didaktik) }\end{array}$ & $\begin{array}{l}\text { Fagenes historie, } \\
\text { væsen, funktion } \\
\text { og erkendelses- } \\
\text { muligheder. Heri } \\
\text { ligger både fagsyn, } \\
\text { dannelsessyn, } \\
\text { videnskabssyn og } \\
\text { læringssyng }\end{array}$ & $\begin{array}{l}\text { Det faglige indholds } \\
\text { legitimationsgrund- } \\
\text { lag - fagdidaktiske } \\
\text { paradigmer som fx } \\
\text { etno-, basis-, fags-, } \\
\text { eksistens- og } \\
\text { udfordringens } \\
\text { didaktik }\end{array}$ & $\begin{array}{l}\text { Hensigtsmæssige } \\
\text { metoder, aktivitets- } \\
\text { former, organisati- } \\
\text { onsformer, evalu- } \\
\text { eringsformer og } \\
\text { læremidler }\end{array}$ \\
\hline
\end{tabular}


Modellen beskriver hvordan fagdidaktikken kan undersøges som "akademisk studie- og forskningsområde" (F. V. Nielsen, 2012, s. 11). Den videnskabelige fagdidaktik kan undersøge et fag i forhold til tre dimensioner: fagets identitet, fagets indhold og fagets praksis. Disse tre dimensioner kan anskues ud fra en deskriptiv eller en normativ position. Eksempelvis kan et fags identitet deskriptivt undersøges ud fra, hvilke basisfag (eller kunst og håndværk) de er funderet i, og normativt hvilke funktion- og erkendelsesmuligheder et fag har. Et andet eksempel er, at et fags indhold deskriptivt kan beskrives ud fra hvilke viden, færdigheder og kompetencer et fag sigter efter, og normativt undersøges ud fra, hvordan fagets viden er legitimeret. Undersøgelsen af fagets legitimation kan for eksempel foretages med udgangspunkt i Nielsens didaktiske grundpositioner (2004): den videnskabsorienterede 'basisfags-didaktik', den elevkulturelle 'etno-didaktik', den samfundsorientrede 'udfordrings-didaktik' og den eksistensorienterede 'eksistens-didaktik'. I vores undersøgelse af Erhvervsinformatiks formelle læreplan bruger vi ovenstående model til at formulere tre overordnede undersøgelsesspørgsmål:

1. fagets identitet, herunder hvad er det for et (eller flere) basisfag som faget er funderet i og hvad er fagets historie, funktioner og erkendelsesmuligheder?

2. fagets indhold, herunder hvilke mål, viden, færdigheder og kompetencer skal eleverne tilegne sig i arbejdet med faget?

3. fagets praksis, herunder hvad er fagets didaktiske principper, metoder, aktivitetsformer, læremidler og evalueringsformer?

Fagets læreplan udgøres her af: a) Bekendtgørelse om grundfag, erhvervsfag, erhvervsrettet andetsprogsdansk og kombinationsfag i erhvervsuddannelserne og om adgangskurser til erhvervsuddannelserne (BEK nr. 692 af 26/o5/2020) og b) Vejledning til Grundfagsbekendtgørelse Erhvervsinformatik (Styrelsen for Undervisning og Kvalitet, 2019). Fremadrettet henvises til disse som henholdsvis Bekendtgørelsen og Vejledningen. Metodisk har vi foretaget en linje-for-linje analyse (Chenail, 2012), hvor begge dokumenter er blevet nærlæst, og illustrative passager er udvalgt til nærmere analyse med henblik på at forstå fagets centrale begreber og antagelser. 


\section{Erhvervsuddannelsernes særegenhed påvirker udvikling af Erhvervsinformatik}

Erhvervsuddannelserne adskiller sig markant fra andre uddannelsestyper, hvilket kan give nogle udfordringer, men også nogle muligheder i forhold til Erhvervsinformatik som fag og faglighed. For at forstå disse udfordringer og muligheder, er det væsentlig at gøre sig en række karakteristika omkring erhvervsuddannelser klart.

\section{Erhvervsuddannelser er først og fremmest erhvervs- og arbejdsmarkedsorienterede}

Dette understreges på Børne- og Undervisningsministeriets (BUVM) hjemmeside om erhvervsuddannelser, hvoraf det fremgår, at "med en erhvervsuddannelse får du adgang til det faglærte arbejdsmarked" (BUVM, 2021). Det fremgår også tydeligt i loven om Erhvervsuddannelser, hvor især tre forhold er interessante i denne sammenhæng:

1. Erhvervsuddannelser har først og fremmest som formål at give uddannelsessøgende "en uddannelse, der giver grundlag for deres fremtidige arbejdsliv, herunder etablering af selvstændig virksomhed"

2. Erhvervsuddannelser har også som formål, at "bidrage til at udvikle de uddannelsessøgendes interesse for og evne til aktiv medvirken i et demokratisk samfund og bidrage til deres personlige udvikling, karakterdannelse og faglige stolthed"

3. Begge dele med det formål "at imødekomme arbejdsmarkedets behov for erhvervsfaglige og generelle kvalifikationer vurderet under hensyn til den erhvervsmæssige og samfundsmæssige udvikling, herunder udviklingen i erhvervsstruktur, arbejdsmarkedsforhold, arbejdspladsorganisation og teknologi, samt for en innovativ og kreativ arbejdsstyrke" (jævnfør LBK nr. 1395 af 28/o9/2020, kapitel 1, §1).

Hertil skal det bemærkes, at erhvervsuddannelserne også har et studieforberedende sigte, idet uddannelserne skal "tilrettelægges således, at de giver eleverne grundlag for videreuddannelse, herunder mulighed for at opnå studiekompetence til relevante videregående uddannelser i tilknytning til erhvervskompetencen" (LBK nr. 1395 af 28/og/2020, kapitel 1, § 1 a.).

Sammenfattende kan det siges, at erhvervsuddannelser overordnet set kvalificerer til fremtidig udøvelse, og for at kunne kvalificere sig til at udøve erhverv, er det nødvendigt, at eleverne 
tilegner sig både erhvervsfaglige, personlige og studieforberedende kompetencer (Hansen \& Karim, 2020), hvilket vi vender tilbage til i delanalyserne.

\section{Erhvervsuddannelser er organiseret som vekseluddannelser}

Størstedelen af de over 100 forskellige erhvervsuddannelser er organiseret ud fra et vekseluddannelsesprincip, som betyder, at eleverne gennemfører deres uddannelse i henholdsvis skolen og på praktiksteder (virksomheder, institutioner med videre). Længden på erhvervsuddannelser varierer og afhænger til dels af elevens forudsætninger. Den typiske længde er på ca. fire år. På de fleste uddannelser, udgør praktikdelen langt størstedelen (2/3) af uddannelsen. Det har betydning for, i hvilken grad erhvervsskolelærere kan påvirke elevernes samlede læring og udvikling. Det betyder også, at elevernes identitet i vid udstrækning formes af praktikstederne, og at der på erhvervsuddannelser er en stor erhvervspædagogisk opgave med at skabe sammenhæng og samspil mellem skole-praktik og teori-praksis.

Den stærke kobling til forskellige erhverv og brancher gør også, at netop redskabsorienteret anvendelse af teknologi, er en del af erhvervsuddannelsernes raison d'être. Dette udelukker ikke nødvendigvis en mere almen teknologiforståelse (jævnfør Basballe, Caspersen, Hansen, Hjort, Iversen \& Kanstrup, 2021), men det kan give udfordringer i forhold til fagets legitimering blandt elever og lærere.

\section{Erhvervsuddannelser er mangfoldige i forhold til indhold og målgrupper}

Betegnelsen 'erhvervsuddannelser' dækker over tre forskellige uddannelsesspor med forskellig opbygning, indhold og målgruppe: for unge (eud), for voksne (euv) og som kombination med gymnasial eksamen (eux). Aktuelt er erhvervsuddannelserne organiseret i fire hovedindgange:

— Omsorg, sundhed og pædagogik

— Kontor, handel og forretningsservice

— Fødevarer, jordbrug og oplevelser

— Teknologi, byggeri og transport

Dette betyder først og fremmest, at 'elevgruppen' på erhvervsuddannelserne er meget heterogen (også inden for de enkelte hovedindgange), hvilket giver nogle didaktiske differentieringsudfordringer eksempelvis i forhold til at motivere og engagere eleverne i forskellige fag og 
fagligheder. Det betyder også, at der er nogle væsentlige forskelle med formål. Hvor intet andet nævnes, er vores fokus dog på eud.

\section{Erhvervsuddannelser styres i vid udstrækning af arbejdsmarkedets parter}

Ministeriet har det overordnede parlamentariske, økonomiske og retlige ansvar for erhvervsuddannelserne, men arbejdsmarkedets parter spiller en central rolle i styringen og udviklingen af erhvervsuddannelserne. Dette sker blandt andet gennem Rådet for de Grundlæggende Erhvervsrettede Uddannelser (REU) og såkaldte faglige og lokale uddannelsesudvalg, som er sammensat af arbejdsgivere og arbejdstagere fra de pågældende jobområder, som uddannelserne uddanner til. Det faglige udvalg beslutter kompetencemålene for uddannelsen og fastsætter i samarbejde med ministeriet rammerne for uddannelsen.

Dette understreger naturligvis arbejdsmarkedsorienteringen i erhvervsuddannelserne, og nok så væsentligt betyder det, at det er de forskellige faglige udvalg, der hver især beslutter, hvorvidt et nyt fag skal indføres på de uddannelser, som udvalget har ansvar for.

\section{Erhvervsuddannelsers praksis er domineret af erhvervspædagogik og -didaktik}

De nævnte karakteristika præger også uddannelsernes undervisningspraksis. Det særlige her er, at de erhvervspraksisser, som eleverne uddanner sig til, udgør omdrejningspunktet for både de pædagogiske og didaktiske overvejelser og lærernes undervisningspraksis. Som vi så ovenfor, er der qua vekseluddannelsesprincippet en forventning om et tæt samspil mellem både teori-praksis og mellem skole- og praktikperioder. Det giver nogle særlige udfordringer, hvor eleverne i erhvervsuddannelserne konstant befinder og bevæger sig i et spændingsfelt mellem egen subjektiv logik og henholdsvis praktikstedernes produktionslogik over for uddannelsesinstitutionens skolelogik (Riis, Rasmussen \& Brodersen, 2019; Jørgensen, 2012; Jørgensen, 2009).

I modsætning til almenpædagogikken, som har rødder i skolastisk tænkning, der knytter sig til skolen som institution og direkte undervisning, har erhvervspcedagogikken rødder i mesterlæren som oplæringsform, hvor eleven i skolen eller lærlingen i praktikperioden gennem selvstændig, men guidet eksperimenteren tilegner sig fagene og erhvervenes praksis og kultur (K. Nielsen, 2012). Hermed lægges der også op til, at det faglige indhold ikke kun tilegnes gennem hovedet, men at krop og sanser anvendes i lige så høj grad.

Den dobbelte fordring, forbundet med erhvervsuddannelsernes sigte mod at forberede eleverne på både arbejdslivet og samfundslivet, udgør også en permanent pædagogisk-didaktisk udfordring. 
I 2019 blev karakterdannelse og faglig stolthed skrevet ind i formålsparagraffen på erhvervsuddannelserne på baggrund af et politisk $\emptyset n s k e$ om at styrke dannelseselementet (Regeringen, 2018). Da der således ikke er tale om (almen-)dannelse som i andre uddannelsestyper, blev der igangsat en større undersøgelse af, hvad de to begreber omhandler, og hvordan de kan imødekommes i erhvervsuddannelsernes praksis (Louw, Gimmler \& Albrechtsen, 2020). Her konstaterer forfatterne, at deres begrebsafklaring af karakterdannelse er, at "det er en karakterdannende proces til faglig stolthed" (Louw, Gimmler \& Albrechtsen, 2020, s. 4), og skriver endvidere:

99 Denne begrebsafklaring gør det for det første muligt at være sensitiv overfor, at hver enkelt erhvervsuddannelse og fag har en historie, et genstandsfelt og en faglighed. Samtidig udgør ovennævnte begrebsafklaring en samlende ramme for arbejdet med karakterdannelse og faglig stolthed på erhvervsuddannelserne, der udspringer af det, som gør erhvervsuddannelserne ens og unikke at de alle er rettet mod et specifikt erhverv.

(Louw, Gimmler \& Albrechtsen, 2020, s. 4).

Informanterne i undersøgelsen skelnede endvidere mellem almendannelse og erhvervsdannelse, som erhvervsuddannelserne skal kunne rumme, men hvor sidstnævnte har de bedste vilkår. Endvidere understregede informanterne, at dannelse på erhvervsuddannelserne sker og bør ske gennem fagene - særligt gennem oplevelsen og udførelsen af handlinger og produkter i praksis. Dannelse må ikke blive for 'boglig'. Derfor er det typisk på grundforløbet, der for uddannelserne udgør det længste samlede uddannelsesforløb, at informanterne ser mulighed for at arbejde med den mere almene dannelse (Louw, Gimmler \& Albrechtsen, 2020, s. 29).

Det er især gennem uddannelsernes erhvervs- og uddannelsesspecifikke fag, at der skabes forbindelse til arbejdslivet, men også i forhold til de mere almene grundfag (for eksempel dansk og matematik) er der en fordring om, at fagene målrettes eller orienteres mod kommende erhverv (jævnfør BEK nr. 1619 af 27/12/2019). Erhvervsdidaktik er karakteriseret ved, at elevernes kommende erhvervsfunktioner og erhvervsopgaver er udgangspunktet for alle didaktiske beslutninger (Hiim \& Hippe, 2014). Det betyder konkret, at traditionelle almene didaktiske kategorier som for eksempel mål, indhold, læringsforudsætninger og rammer tænkes og praktiseres i forhold til kommende erhverv, hvilket giver yderligere relationel kompleksitet til lærerens didaktiske opgave.

Det giver også nogle særlige fagdidaktiske vilkår, som skal indgå i overvejelser om eksempelvis et nyt grundfags ud- og 
afvikling. På erhvervsuddannelser er grundfag typisk udviklet på baggrund af basisfag, hvilket som tidligere nævnt også er tilfældet for Erhvervsinformatik, og også her er der en fagdidaktisk opgave:

99 Fag er et felt, der er skåret ud af en anden virkelighed end skolens og bearbejdet til brug i uddannelse og undervisning. Erhvervet kan ikke overføres som helhed til uddannelsen, men udvalgte dele af erhvervets virkelighed kan skæres ud og bearbejdes, så det bliver til undervisning i uddannelsen. Hele den matematiske videnskab kan heller ikke overføres til matematikundervisningen, derfor må der vælges ud af denne videnskab og bearbejdes til noget, der kan blive meningsfuldt i uddannelse og undervisning. (Svejgaard \& Størner, 2010, s. 19)

Når der således skal foretages en fagdidaktisk analyse af Erhvervsinformatik, er det væsentligt at være opmærksom på erhvervsuddannelsernes særegenhed, der også gælder det pædagogiske-didaktiske område.

\section{Delanalyse 1 - Erhvervsinformatiks identitet}

I delanalyse 1 er fokus på læreplanens hvorfor, det vil sige, hvordan begrundes og legitimeres faget, hvad er det for et (eller flere) basisfag, som faget er funderet i, og hvad er fagets historie, funktioner og erkendelsesmuligheder? I forhold til Erhvervsinformatiks identitet og formål guides erhvervsuddannelseslærerne på vej i første kapitel af både bekendtgørelsen og vejledningen, hvor fagets kompetenceområder listes og to centrale faglige begreber, henholdsvis digitale artefakter og digitale teknologier, defineres.

\section{Erhvervsinformatiks korte historie}

Som en del af den daværende regerings nationale naturvidenskabsstrategi, blev det i 2018 besluttet at udvikle et nyt grundfag om teknologiforståelse til erhvervsuddannelserne (Undervisningsministeriet, 2018). På den baggrund nedsatte Styrelsen for Undervisning og Kvalitet (STUK) i efteråret 2018 en arbejdsgruppe bestående af deltagere fra professionshøjskoler og erhvervsuddannelser til at udvikle det faglige indhold i det nye fag, der kom til at hedde Erhvervsinformatik. Arbejdsgruppen fik endvidere sparring fra forskellige brancheorganisationer og personer med ekspertise i lignende fagligheder (EMU, 2021). 
Erhvervsinformatik er udviklet med afsæt i de eksisterende basisfagligheder design, datalogi og informatik (Basballe, Caspersen, Hansen, Hjort, Iversen \& Kanstrup, 2021; Iversen, Dindler \& Smith, 2019; Caspersen, Iversen, Nielsen, Hjort \& Musaeus, 2018). Endvidere er faget udviklet med tydelig inspiration fra grundskolens nye fag Teknologiforståelse, hvor der er personsammenfald mellem de eksperter og praktikere, der har været inviteret til at udvikle faget i henholdsvis grundskolen og på erhvervsuddannelserne. Dog er Erhvervsinformatik tydeligt målrettet de erhverv og brancher, som eleverne på erhvervsuddannelserne uddanner sig til. Det betyder blandt andet, at kompetencemålene for Erhvervsinformatik adskiller sig fra kompetencemålene for Teknologiforståelse, idet målene i førstnævnte er færre og har et bevidst erhvervsrettet sigte.

I modsætning til udvikling af Teknologiforståelse, der i grundskolen blandt andet har omfattet et systematisk afprøvningsforsøg på 46 danske grundskoler fra 1. kl - 9. kl (tekforsøget.dk), er der ikke lignende tiltag på erhvervsuddannelserne, hvor lærerne derfor ikke har samme muligheder for at opkvalificere deres fagfaglige og erhvervspædagogisk-didaktiske viden omkring udvikling af faget og fagligheden. Blandt de 19 erhvervsuddannelser, der aktuelt arbejder med udvikling og afprøvning af faget, er det typisk uddannelser, der i forvejen er teknologitunge, og dermed i en vis udstrækning er vant til at arbejde med erhvervsrettet digital teknologi (Andersen, 2021).

\section{Erhvervsinformatiks relation til eksisterende fag}

Ligesom i grundskolen, har erhvervsuddannelserne også mulighed for at afvikle Erhvervsinformatik som enten selvstændigt grundfag eller som faglighed, der integreres i allerede eksisterende fag. Teknologi- og designfag indgår allerede i stort omfang inden for de fire hovedindgange på erhvervsuddannelserne, om end naturligvis i forskellige udmøntninger afhængig af uddannelserne. Her er det dog værd at bemærke, at teknologidelen i teknologiforståelse som fænomen og i faget Erhvervsinformatik henviser til digital teknologi, og dette gør sig også gældende i forhold til digital design (Iversen, Dindler \& Smith, 2020). Det digitale aspekt gør dermed, at der ikke nødvendigvis er overlap mellem Erhvervsinformatik og eksisterende fag, men det anbefales i vejledningen, at faget så vidt muligt tænkes sammen med både andre grund-, erhvervs- og uddannelsesspecifikke fag (Styrelsen for Undervisning og Kvalitet, 2019, s. 27).

Nok så væsentligt skal det bemærkes, at i forbindelse med etablering af Erhvervsinformatik, blev det endvidere besluttet at udfase det tidligere brede og mere almendannende grundfag Informationsteknologi (jævnfør BEK nr. 37 af 15/o1/2020, bilag 11). Samtidig blev flere grundfagsbekendtgørelser dog justeret, så der nu er 
indskrevet elementer fra Informationsteknologi - eksempelvis i Dansk og Matematik.

\section{Erhvervsinformatiks identitet og formål}

Relevansen for faget baseres på den digitale udvikling, der præger vores liv, og i faget Erhvervsinformatik henvises eksplicit til elevernes kommende arbejdsliv. I vejledningen til fagbilaget er der flere passager, der understreger vigtigheden af, at eleverne klædes på til at kunne begå sig kompetent på et digitaliseret arbejdsmarked, som eksempelvis:

99 I langt de fleste erhverv, vil medarbejdere på den ene eller anden måde i stigende omfang skulle betjene og indgå i interaktion med digitale artefakter på en sikker, effektiv og fagligt hensigtsmæssig måde. I en verden med øget digitalisering fordrer samfunds- og erhvervsudviklingen på tværs af brancher, at der uddannes faglærte med adgang til og viden om digitale artefakter. Derfor har faget erhvervsinformatik fokus på at give eleverne styrkede forudsætninger for i en professionel og erhvervsfaglig sammenhæng at forstå, anvende, vurdere og medskabe digitale teknologier og artefakter, inden for deres fagområde.

Samtidig bidrager faget til elevernes digitale myndiggørelse og giver redskaber for den enkelte til at forstå, anvende og agere hensigtsmæssigt i forskellige sammenhænge med digital teknologi både inden for erhvervene og som borger i et samfund med øget digitalisering.

(Styrelsen for Undervisning og Kvalitet, 2019, s. 5)

Disse begrundelser udmønter sig i to overordnede formuleringer af fagets identitet i bekendtgørelsen:

- Eleverne i erhvervsuddannelserne skal rustes bedre til at imødegå de krav om digital kompetence, som de møder på arbejdsmarkedet og samtidig lære at forholde sig til den digitale udviklings særlige udfordringer.

— Faget skal bidrage til elevernes digitale dannelse. Faget indeholder konkret praktisk arbejde med at skabe digitale løsninger og giver kompetencer til at vurdere digitale teknologier og automatisering. (BEK nr. 692 af 26/05/2020, bilag 6, 1.1.)

Hermed er det tydeliggjort, at faget Erhvervsinformatik er skabt for at imødekomme en tidstypisk problemstilling om digitalisering, og at faget dermed henter en del af sin begrundelse og legitimitet 
i et udfordringsdidaktisk paradigme (Krogh, Qvortrup \& Christensen, 2018). Ser man nærmere på fagets formål, fortsætter arbejdsmarkedsorienteringen og det erhvervsrettede fokus, idet eleverne skal:

99

[...] arbejde med kendte og nye teknologier, som kan anvendes på arbejdsmarkedet. Faget skal give eleverne kompetencer til at være værdiskabende medarbejdere og dygtige iværksættere i et samfund præget af stigende digitalisering og til at kunne agere som aktive og ansvarsbevidste borgere.

(Styrelsen for Undervisning og Kvalitet, 2019, s. 5)

Som vi så tidligere skal erhvervsuddannelser generelt - under hensyn til arbejdsmarkedets behov, faglige mobilitet og elevens behov - bidrage til udvikling af elevens erhvervsfaglige og personlige kompetencer. Hertil kommer i et vist omfang bidrag til elevernes studieforberedende kompetencer, om end dette aspekt fylder væsentlig mere på eux end på eud.

Erhvervsfaglige kompetencer drejer sig om, at eleverne gennem uddannelsen tilegner sig viden, færdigheder og kompetencer, der sætter dem i stand til at håndtere faglige udfordringer inden for et af erhvervsuddannelsens fire hovedområder. Erhvervsinformatiks identitet og formål matcher således erhvervsuddannelsernes overordnede formål om først og fremmest at uddanne tidssvarende og kvalificeret arbejdskraft i form af "værdiskabende medarbejdere og dygtige iværksættere" (som det fremgår af citatet ovenfor).

De personlige kompetencer handler om, at eleverne på ene side udvikler sig til at blive frie, autonome og myndige individer. Her er centrale kompetencer for eksempel selvstændig stillingtagen, samarbejde og kommunikation. Indenfor erhvervsuddannelse kan personlige kompetencer imidlertid også forstås som det at udvikle et tilhørsforhold til en social praksis og at udvikle identitet i forhold til at deltage i en sådan (Jakobsen \& Lausch, 2014; Jørgensen, 2012). At være elev på en erhvervsuddannelse er dermed en læreproces, som både handler om at tilegne sig kompetencer, at blive en del af et bestemt praksisfællesskab og at kunne udvikle både personlig relevans, karakter og faglig stolthed i forhold til kvalifikationer og praksisfællesskaber, både i skolen og i praktikken. De personlige aspekter ses mest tydeligt i formålet om digital myndiggørelse.

De studieforberedende kompetencer går på, at eleverne tilegner sig grundlæggende faglig viden inden for en række faglige felter som matematik, læsning, mundtlig og skriftlig kommunikation samt informationsteknologi med henblik på at styrke grundlaget 
for fremtidig efter- og videreuddannelse inden for et af de fire erhvervsspor erhvervsuddannelserne retter sig i mod. Dette aspekt er umiddelbart det mindst synlige i Erhvervsinformatiks identitet og formål.

Det er i fagets formål, at man ser de første antydninger af fagets basisfaglige didaktiske position (Nielsen, 2004). Allerede her anvendes fagbegreber som eksempelvis digitale artefakter og digitale teknologier, der defineres fagspecifikt i indledningen til vejledningen. Hermed lægges der fra start op til fokus på en række basisfagligheder, der også kan ses i et studieforberedende perspektiv.

\section{Delanalyse 2 - Erhvervsinformatiks indhold}

I delanalyse 2 er fokus på læreplanens hvad, det vil sige hvilke mål, viden, færdigheder og kompetencer skal eleverne tilegne sig i arbejdet med faget? I forhold til Erhvervsinformatiks indhold guides erhvervsuddannelseslærerne på vej i både bekendtgørelsen og vejledningen, hvor dette beskrives under overskriften 'faglige mål og fagligt indhold'. Disse afsnit har fokus på kompetenceområder, faglige mål, kernestof og supplerende stof.

\section{Erhvervsinformatiks kompetenceområder og kernestof}

Erhvervsinformatik udbydes på niveauerne F-C og uddannelsestiden er sat til henholdsvis to uger for eud og tre uger for eux. Som det er tilfældet med andre grundfag på erhvervsuddannelserne, skal de faglige mål for Erhvervsinformatik opfyldes gennem arbejde med både kernestof (der er obligatorisk på de pågældende niveauer) og supplerende stof, hvor der er større frihed. Kernestoffet skal udgøre $85 \%$ af den vejledende uddannelsestid. Faget retter sig mod tre overordnede kompetenceområder, hvortil der er knyttet særlig viden og færdigheder udtrykt i kernestoffet, der stiger i sværhedsgrad i takt med niveauerne. Kompetenceområderne og kernestof på det basale niveau F, fremgår i Tabel 2 herunder. 
Tabel 2.

Kompetenceområder og kernestof på niveau

F i Erhvervsinformatik (BEK nr. 692 af

26/05/2020, bilag 6, 2.1. og 2.2.).

\begin{tabular}{|c|c|}
\hline Kompetenceområde & Kernestof (niveau F) \\
\hline Digital myndiggørelse & $\begin{array}{l}\text { Sikkerhed og adfærd } \\
\text { - Cypersikkerhed } \\
\text { - Informationsspredning og adfærd } \\
\text { - Erhvervsrettet brug af data* } \\
\text { - Love og regler ifm. data } \\
\text { Analyse af digitale artefakter } \\
\text { - Teknologianalyse } \\
\text { - Formålsanalyse } \\
\text { - Brugsstudier } \\
\text { - Konsekvensvurdering } \\
\text { *) Reduceres til fodspor i vejledningen }\end{array}$ \\
\hline $\begin{array}{l}\text { Erhvervsrettet digital } \\
\text { udvikling }\end{array}$ & $\begin{array}{l}\text { Innovations- og designprocesser } \\
\text { - Rammesættelse } \\
\text { - Idégenerering } \\
\text { - Inkrementel innovation }\end{array}$ \\
\hline $\begin{array}{l}\text { Teknologisk handleevne } \\
\text { og computationel } \\
\text { tankegang }\end{array}$ & $\begin{array}{l}\text { Programmering: Funktioner, variable, sekvenser, løkker og forgreninger } \\
\text { Afprøvning og fejlretning } \\
\text { Omsætning af problemløsninger til algoritmer gennem dekomposition, } \\
\text { abstraktion, mønstre og generaliseringer } \\
\text { Datatyper }\end{array}$ \\
\hline
\end{tabular}

Det bemærkes også, at det supplerende stof "vælges med henblik på at bibringe faglig fordybelse og branchespecifikke emner, som ikke er dækket af kernestoffet" (jævnfør Styrelsen for Undervisning og Kvalitet, 2019, s. 24). Dele af det supplerende stof kan endvidere vælges i samarbejde med eleverne, hvis muligt.

Det fremhæves både i bekendtgørelsen og i vejledningen, at begreberne 'digitale artefakter' og 'digitale teknologier' er centrale 
i faget og dets forståelse af teknologi. I bekendtgørelsen stilles der endda et spørgsmål herom, som faget skal søge at svare på:

99 Gennem analyse af digitale artefakter opnås forståelse af den teknologi, der ligger bag og dennes potentialer - med andre ord: gør teknologien det, som vi ønsker, den skal gøre, og hvilke andre anvendelsesmuligheder kan man forestille sig, teknologien rummer?

(BEK nr. 692 af 26/05/2020, bilag 6, 2.)

Her ses det også tydeligt, hvordan analyse af teknologi og forestillinger om alternativer knyttes til opnåelse afforståelse, hvilket stemmer godt overens med de antagelser, der ligger i basisfagene. Det er i øvrigt et af de få steder i vejledningen, hvor der ikke eksplicit skabes direkte forbindelse til arbejdsmarkedet. Fokus på de erhvervsfaglige kompetencer, som eleverne forventes at opnå gennem faget, kommer dog tydeligt til udtryk inden for kompetenceområderne.

\section{Kompetenceområdet Digital myndiggørelse}

Ifølge vejledningen omhandler dette kompetenceområde:

99

[...] kritisk, refleksiv og konstruktiv undersøgelse af betydningen af indførelse af digital teknologi og automatisering i de erhverv, som eleverne uddanner sig til, herunder forståelse for sikkerhed, etik og konsekvenser ved digitale teknologier.

(Styrelsen for Undervisning og Kvalitet, 2019, s. 8)

Om end der i de konkrete mål også nævnes digitale artefakters betydning for samfundet bredt set, så ses det, hvorledes hovedfokus er på at uddanne til arbejdsmarkedet. Mens man kunne have forventet, at digital myndiggørelse (også) ville fokusere på elevernes mere almene digitale dannelse og personlige kompetencer, så er både mål og tilhørende kernestof klart rettet mod de erhverv og brancher, som eleverne uddanner sig til. Det fremhæves endda, idet det fremgår, at:

99 Det er en særlig pointe, at der anlægges en erhvervsfaglig vinkel på området. Det er således ikke dækkende kun at arbejde med elevernes private kommunikation og digitale fodspor på eksempelvis sociale medier.

(Styrelsen for Undervisning og Kvalitet, 2019, s. 10)

Det er med andre ord ikke udelukket at arbejde med elevernes personlige digitale liv, men fokus bør primært være på deres kommende 
arbejdsliv. Dermed er der risiko for, at digital myndiggørelse reduceres til digitalt myndiggjorte arbejdstagere. I dette kompetenceområde er der også tydelige basisfaglige elementer med emner som cybersikkerhed, informationsspredning og brug af data og med udvikling af foerdigheder $\mathrm{i}$ at foretage faglige analyser af digitale artefakter så som gennem teknologianalyse og brugsstudier. Endvidere er måden, hvorpå eleverne kan arbejde med forskellige faglige teknologianalyser eksemplificeret i vejledningen (Styrelsen for Undervisning og Kvalitet, 2019, s. 11-12).

\section{Kompetenceområdet Erhvervsrettet digital udvikling}

Ifølge vejledningen omhandler dette kompetenceområde:

99

[...] konkret praktisk arbejde, som leder frem mod udvikling eller redesign af digitale artefakter, herunder tilrettelæggelse og gennemførelse af iterative designprocesser samt modifikation og videreudvikling af digitale artefakter med relevans i en erhvervsfaglig kontekst.

(Styrelsen for Undervisning og Kvalitet, 2019, s. 13)

Inden for dette kompetenceområde, er der ikke overraskende også fokus på det erhvervsrettede. Af vejledningen fremgår det endvidere, at eleverne "får en bedre forståelse af, hvilke overvejelser, der ligger bag udviklingen af digitale teknologier og artefakter, som andre har skabt, og som de selv skal anvende i deres erhverv" (Styrelsen for Undervisning og Kvalitet, 2019, s. 14). Herigennem bliver det tydeligt, at forståelse primært handler om at kunne afdække intentioner i forhold til en erhvervsrettet kontekst. De erhvervsfaglige kompetencer tilgodeses således i dette kompetenceområde, mens de personlige kompetencer i dette tilfælde drejer sig om at kunne arbejde mere eller mindre selvstændigt afhængigt af fagniveau. Også i dette kompetenceområde ses der tydelige basisfaglige elementer, hvor fokus er på design, og der skal opnås færdigheder inden for innovations- og designprocesser. Her eksemplificeres også i vejledningen, hvorledes eleverne kan arbejde med sådanne processer og det indstilles, at eleverne introduceres til forskellige fagbegreber.

\section{Kompetenceområdet Teknologisk handleevne og computationel tankegang \\ Ifølge vejledningen omhandler dette kompetenceområde:}


99

[...] anvendelse af grundlæggende viden om netværk, forståelse af algoritmiske forskrifter, programmering, logisk og algoritmisk tænkning, abstraktion og mønstergenkendelse, datamodellering samt test og afprøvning.

(Styrelsen for Undervisning og Kvalitet, 2019, s. 18)

I vejledningen præciseres det, at eleverne skal arbejde med kompetenceområdet "til løsning af problemstillinger i en erhvervsfaglig kontekst" (Styrelsen for Undervisning og Kvalitet, 2019, s. 18), og eleverne skal tilegne sig en grundloeggende forståelse og praksiserfaring for at opnå målene:

99 Populært sagt skal eleverne have åbnet den digitale 'blackbox' og have en grundlæggende forståelse og praksiserfaring med, hvordan artefakterne arbejder, virker, håndterer data og løser problemer.

(Styrelsen for Undervisning og Kvalitet, 2019, s. 18)

Som tilfældet var i de to forrige kompetenceområder, er der ikke umiddelbart fokus på elevernes personlige kompetencer, medmindre man opfatter computationel tænkning som et sprog, der skal læres på linje med andre sprog, som en kulturfærdighed. I dette kompetenceområde er der, i højere grad end de forrige, fokus på, at eleverne selv skal skabe eller konstruere dele af digitale artefakter. Teknologisk handleevne knyttes dermed til en særlig og snæver del af faget. Det præciseres dog også, at eleverne "ikke skal være programmører" (Styrelsen for Undervisning og Kvalitet, 2019, s. 21), men at arbejdet med programmering i sig selv vil bidrage til den grundlæggende forståelse. Der henvises igen til flere definitioner af fagbegreber, og der eksemplificeres med fokus på erhvervsområder. Forbindelsen til basisfagene datalogi og informatik er meget tydelig her, og kernestoffet her minder til forveksling om det, som ses i Informatik-faget på gymnasieuddannelserne hhx og htx.

\section{Delanalyse 3 - Erhvervsinformatiks praksis}

I delanalyse 3 er fokus på læreplanens hvordan, det vil sige, hvad er fagets didaktiske principper, metoder, aktivitetsformer, læremidler og evalueringsformer? I forhold til Erhvervsinformatiks inten- 
derede praksis guides erhvervsuddannelseslærerne på vej i både bekendtgørelsen og vejledningen, hvor dette går under overskriften 'tilrettelæggelse'. Disse afsnit har fokus på didaktiske principper, arbejdsformer, it i undervisningen og samspil med andre fag. I vejledningen henvises endvidere til yderligere inspiration, eksemplificeringer og materiale på EMU.dk, som vi dog undlader at forholde os til i denne analyse.

\section{Didaktiske principper for Erhvervsinformatik}

I nordisk skoletradition blev fagdidaktik uddifferentieret som en specialiseret gren af didaktikken og dermed gjort til et selvstændigt kundskabsområde fra omkring 1960'erne. Dermed blev begrebet almen didaktik udtrykt som noget, der i højere grad beskæftigede sig med overordnede didaktiske spørgsmål om eksempelvis didaktiske kategoriers væsen, udtryksform, karakter og indbyrdes relationer, mens blikket på det mere mål- og indholdsorienterede blev overladt til fagdidaktikken (Krogh, Qvortrup \& Christensen, 2018). Den didaktikopfattelse, der danner afsæt for beskrivelse af Erhvervsinformatik i vejledningen, er imidlertid meget bred og indebærer både almendidaktiske og fagdidaktiske elementer.

Undervisning i grundfag på erhvervsuddannelser skal helt overordnet tilrettelægges ud fra de enkelte skolers fælles pædagogiske didaktiske grundlag (FPDG), som er en lovpligtig beskrivelse af skolernes lokale pædagogiske-didaktiske værdier og målsætninger (jævnfør Bekendtgørelsen). FPDG udtrykker prioriteringer i en given periode og kan spænde vidt fra fokus på didaktiske principper for undervisningen (for eksempel undervisningsdifferentiering) til øget samarbejde med lokale og regionale praktiksteder. Loven om erhvervsuddannelser fastslår endvidere, at skoleundervisningen, under hele uddannelsesforløbet, skal omfatte både praktisk og teoretisk undervisning med henblik på at give eleverne fornødne generelle og specielle kvalifikationer, og at dette skal gøres på en helhedsorienteret måde (LBK nr. 1395 af 28/o9/2020, kapitel 4, § 22). Lokale prioriteringer og helhedsorientering er dermed forhold, der altid skal tænkes med i udmøntninger af læreplaner på erhvervsuddannelserne. Det fremgår således også i indledningen til vejledningen, at den understøtter "en helhedsorienteret tilgang med eksempler fra undervisningspraksis, som kan bidrage til faglig og pædagogisk fornyelse" (Styrelsen for Undervisning og Kvalitet, 2019, s. 1).

Ifølge vejledningen skal undervisningen organiseres omkring temaer og projekter med erhvervsfaglig relevans for den enkelte uddannelsesretning. Det fremhæves, at elevernes oplevelse af faget som værende vedkommende og direkte anvendeligt i faglige 
sammenhænge skal sikres gennem 'erhvervsfaglig toning' (Styrelsen for Undervisning og Kvalitet, 2019, s. 25). I vejledningens afsnit om tilrettelæggelse indgår også et underafsnit om 'didaktiske principper'. De samme didaktiske principper uddybes yderligere på EMU.dk, hvor der tilknyttes forklaringsvideoer og referencer til, hvorfra man henter den didaktikforståelse, som faget abonnerer på.

De konkrete didaktiske principper er henholdsvis 'Use-modifycreate-progression', 'Stepwise Improvement' og 'Worked Examples' (Styrelsen for Undervisning og Kvalitet, 2019, s. 25), som alle er at genfinde i de 'Didactical Design Principles' som Caspersen \& Nowack har præsenteret for faget Informatik (Caspersen og Nowack, 2013, s. 140-141; Caspersen, 2018). Caspersen og Nowack præsenterer yderligere to principper eller strategier, som Caspersen (2018) også kalder det, henholdsvis A learning activity is not (necessarily) the same as a knowledge area og Learning activities should be application-oriented, men disse er i sig selv indlejrede i Vejledningens beskrivelse af henholdsvis identitet, formål og arbejdsformer. Endvidere præciseres det, at fagbilaget ikke udelukker andre didaktiske tilgange til faget. De nævnte didaktiske principper forklares med eksempler på digitale artefakter og digitale teknologier, og det fremhæves, hvordan disse kan understøtte udvikling af en computationel tankegang. Der er således tænkt både erhvervs- og fagdidaktisk i forhold til fagets udmøntning.

\section{Arbejdsformer i Erhvervsinformatik}

I forhold til arbejdsformer er der tænkt mere almendidaktisk, idet der i første omgang foreslås vekslen mellem overbliksskabende forløb, eksperimenter, øvelser og projekt(er). Her fremhæves også princippet om anvendelsesorientering som tilgang til fagets stof. Det bemærkes imidlertid også, at når eleverne skal anvende faglig viden og metoder, er det med henblik på at skabe løsningsforslag til "et konkret og virkelighedsnært problem inden for deres erhvervsfaglige hovedområde eller uddannelse", og det præciseres, at løsningsforslaget skal være "et værdiskabende digitalt artefakt (eller dele heraf), der præsenteres og evalueres" (Styrelsen for Undervisning og Kvalitet, 2019, s. 26).

Det anbefales, at eleverne arbejder både individuelt og i grupper i løbet af undervisningen. Herudover skal eleverne løbende dokumentere deres arbejde og progression i faget via portfolio, hvilket lægger op til portfoliodidaktik, der i sig selv kan være en ny måde at undervise og evaluere på, idet det på én gang både er en evalueringsform, et pædagogisk redskab og et didaktisk greb (Lund, 2008). Derfor henvises der også til yderligere materiale herom, og i det efterfølgende hovedafsnit 
om 'dokumentation' gives eksempler på, hvilke dele af de tre kompetenceområder, der med fordel kan dokumenteres i elevernes porteføljer (Styrelsen for Undervisning og Kvalitet, 2019, s. 28).

\section{It i erhvervsinformatikundervisningen}

Ikke overraskende fremgår det af vejledningen, at 'it og medier' fylder meget i faget som redskaber for læreprocesser, men også i arbejdet med udvikling af digitale artefakter. Programmering og programmeringssprog fremhæves som værende centrale elementer i faget, og her påpeges det, at eleverne må forventes at have vidt forskellige forudsætninger, hvorfor der skal undervisningsdifferentieres for at sikre individuel progression. I afsnittet om it gøres der også opmærksom på, at det er gennem arbejdet med digitale artefakter og digitale teknologier, at eleverne opnår både specifikke faglige digitale kompetencer og almene digitale kompetencer. Dette understreges også i følgende formulering: 99

Gennem undervisningen skal faget bidrage til at udvikle elevernes digitale myndiggørelse; analytisk, konstruktiv, kritisk og kreativ forståelse og anvendelse af digitale teknologier.

(Styrelsen for Undervisning og Kvalitet, 2019, s. 27)

Her ser vi endnu et af de få steder i vejledningen, hvor der ikke skabes direkte relation til den erhvervsfaglige kontekst. Hvad angår fagets læremidler i form af konkrete digitale artefakter og teknologier, henvises til "et stort udbud af frit tilgcengelige undervisningsplatforme og netbaserede applikationer, der kan understøtte læreprocesserne i faget" (Styrelsen for Undervisning og Kvalitet, 2019, s. 27 - vores kursivering). I et fag, hvor formålet er, at eleverne udvikler kritisk forståelse overfor digitale artefakter og teknologier, er det tankevækkende, at lærerne på denne måde opfordres til at anvende kommercielle teknologier.

Endelig anbefales det, som tidligere nævnt, at faget, så vidt muligt, gennemføres i samspil med andre fag i uddannelsen, hvorved det overordnede princip om en helhedsorienteret tilgang til undervisningen fremhæves. Som det også var tilfældet i forhold til Erhvervsinformatiks kernestof inden for kompetenceområdet 'Teknologisk handleevne og computationel tænkning', er der også i vejledningen om tilrettelæggelse klare paralleller til gymnasiefaget Informatik, hvilket understreger den dominerende basisfaglighed. 


\section{Konklusion}

Med denne artikel har formålet været at bidrage til en fagdidaktisk analyse af erhvervsuddannelsernes nye grundfag Erhvervsinformatik. Gennem tre delanalyser har vi søgt svar på, hvordan Erhvervsinformatiks identitet, indhold og intenderede praksis, er tænkt i forhold til erhvervsuddannelsernes særkende og hensigten med at uddanne i den nye faglighed. Hermed bidrager artiklen specifikt med fagdidaktisk viden om den nye teknologiforståelsesfaglighed, som denne tænkes i læreplaner inden for erhvervsuddannelser og mere generelt med viden om erhvervsuddannelser i forskningsfelter (fagdidaktik og teknologiforståelse), der ellers typisk er domineret af andre uddannelsestyper.

Som vi så i indledningen, fremhæves det, at teknologiforståelsesfagligheden baserer sig på et grundlag af både naturfaglige, humanistiske og samfundsfaglige elementer. Her har analyserne vist, at Erhvervsinformatik på indholdssiden særligt domineres af naturfaglige basisfag som datalogi og informatik. Heroverfor er det intentionen, at fagets designfaglighed, særligt den skandinaviske, participatoriske tilgang skal sikre, "at eleverne ikke kun lærer programmeringsfærdigheder i skolen, men også bliver involveret i en sådan grad, at de kan begynde at erkende og skabe med teknologien" (Wagner, Iversen \& Caspersen, 2020, s.10). Imidlertid kan vores analyser give anledning til at problematisere dels vægtningen mellem de forskellige basisfag, og dels det forhold, at designfagligheden primært tænkes udmøntet som et processuelt didaktisk greb, det vil sige som et middel til at nå specifikke mål, fremfor som et tungere indholdselement, hvor der kunne være fokus på de mere humanistiske og samfundsfaglige aspekter, herunder ikke mindst teknologifilosofi og -historie.

Hvad angår erhvervsuddannelsernes scerkende, så har analyserne vist, at faget i stor udstrækning matcher uddannelsernes overordnede formål om at uddanne kvalificeret arbejdskraft, og at der gennem fagets indhold og intenderede praksis er tænkt både fag- og erhvervsdidaktisk. Med fagets eksplicitte fokus på erhvervsfaglige kompetencer og anvendelse i erhvervsfaglige kontekster søges der også at imødekomme erhvervsuddannelsernes vekselprincip gennem koblinger og samspil mellem teori-praksis og skole-praktik. Det kan imidlertid diskuteres i hvilken udstrækning lærere på særligt grundforløbet, hvor faget primært udbydes aktuelt, kan motivere og engagere elever, der endnu ikke har den store erhvervspraktiske viden og erfaring. Omvendt viser forskning i erhvervsuddannelser (Hansen \& Karim, 2020; Riis, Rasmussen \& Brodersen, 2019), at det netop er de erhvervsfaglige og erhvervspraktiske aspekter, der typisk virker 
motiverende i sig selv, idet der herigennem markeres den største forskel i forhold til andre uddannelsestyper, eleverne har erfaringer med.

Desuagtet ovenstående, leder dette imidlertid også frem til en mere generel bekymring omkring den didaktiske rammesætning af faget, hvor didaktik reduceres til at være et spørgsmål om 'tilrettelæggelse'. I tysk-skandinavisk tradition knytter begrebet didaktik sig tæt til det at undervise som en teoretisk funderet disciplin og ikke alene til den mere snævre instruktionslære (Dohn \& Hansen, 2016). En bredere didaktikforståelse ville derfor også inkludere mere teoretiske overvejelser om grundlæggende didaktiske spørgsmål, særligt undervisningens og fagets 'hvorfor'. Som analyserne har vist, er Erhvervsinformatik præget af en udfordringsdidaktisk tænkning, men der gives reelt ingen teoretiske begrundelser herfor, i og med fokus i vejledningen er på at legtimere det basisfaglige grundlag. Som sådan er erhvervsuddannelseslærerne overladt til selv at gennemskue faget og faglighedens bagvedliggende intentioner og antagelser. Her adskiller erhvervsuddannelsernes rammer for udvikling af fagligheden sig markant i forhold til eksempelvis grundskolen. Den tilsyneladende bagvedliggende antagelse om, at erhvervsuddannelseslærerne allerede er fagfagligt kvalificerede må derfor problematiseres, da faget også er tænkt i samspil med fag, hvor lærerne ikke nødvendigvis har sådanne forudsætninger. Hertil kommer, at selve det at lære at undervise i en $n y$ faglighed, efter vores vurdering, ikke kan klares alene via en vejledning og tilhørende inspirationsmateriale på en hjemmeside.

Hensigten med at uddanne i den nye faglighed er, som vi så indledningsvist, at etablere en fundamental teknologiforståelse med et almendannende formål op gennem uddannelsessystemet. I tilfældet med Erhvervsinformatik synes denne ambition ikke umiddelbart at kunne indfries, men det kan også diskuteres, om det overhovedet er et hensigtsmæssigt formål på erhvervsuddannelser. Der synes ikke at være tvivl om, at erhvervslivet og arbejdsmarkedet i det hele taget har brug for digitalt myndiggjorte arbejdstagere, og det er erhvervsuddannelsernes primære formål at sørge herfor. På den anden side, skal eleverne på erhvervsuddannelserne stadig også kunne fungere som digitalt myndiggjorte eller dannede borgere, og her kan vi godt være bekymrede for fagets præmis om, at det at arbejde med digitale artefakter og teknologier i en erhvervsmæssig kontekst i sig selv er nok til, at eleverne også udvikler mere personlig viden og kompetencer på det digitale område.

Det kan i denne sammenhæng være værd at overveje, at teknologi bredt favnende også repræsenterer overordnede almenmenneskelige 
problemstillinger og ikke kun løsninger og viden, færdigheder, kompetencer, der bliver efterspurgt på arbejdsmarkedet. Teknologi kan virke fremmedgørende og helt grundlæggende ændre omstændighederne for det at indgå i eksempelvis arbejdsrelationer, udføre opgaver og i det hele taget påtage sig arbejde, så teknologi i sig selv er ikke et løsen. Basisfagligheder som datalogi og informatik kan sikre fagets erhvervsorientering, men burde også kunne være anledning til udvikling af dybere forståelse, såfremt der blev tænkt mere i en kombination mellem det erhvervsrettede og det mere brede og til tider ganske udefinerbare, nemlig det menneskeligt dannende.

Taget i betragtning, at det mere almendannende grundfag, Informationsteknologi, blev udfaset samtidig med Erhvervsinformatiks indførelse, kan der opstå et videns- og kompetencehul. Her er det tanken, at eleverne på erhvervsuddannelserne, på sigt, kommer digitalt myndiggjorte eller dannende fra grundskolen og dennes teknologiforståelsesfag. Det ligger dog ikke lige om hjørnet, og det er heller ikke alt stof, der fæstner sig i første omgang. Herudover er det også værd at bemærke, at store dele af det arbejdsmarked, som erhvervsuddannelserne retter sig imod, i stadig stigende grad, også efterlyser kandidater med mere almene digitale kompetencer og dannelse. Så meget desto mere, kan der være grund til at gentænke de dele af Erhvervsinformatik, hvor der med relativt få ændringer i kernestoffet kunne gøres bedre plads til nogle af de mere humanistiske og samfundsfaglige aspekter, som vi tidligere har efterlyst. Det kunne måske også være med til at udbrede faget, så det kom til at omfatte flere af de over 100 erhvervsuddannelser og dermed kom langt flere elever, men også flere arbejdspladser til gode.

I gap-analysen omkring teknologiforståelse fra Den nationale kapacitetsgruppe (jævnfør Basballe, Caspersen, Hansen, Hjort, Iversen \& Kanstrup, 2021), fremhæves det, at det nye i fagligheden blandt andet består i målet om at udvikle en fundamental forståelse af teknologi, der samtidig sættes i et modsætningsforhold til en redskabsorienteret tilgang. For erhvervsuddannelserne vil dette være en falsk modsætning, idet anvendelse af de forskellige erhverv og branchers redskaber, herunder også digitale artefakter og teknologier, netop er en del af uddannelsernes raison d'être og dermed fagets legitimering for både elever, lærere og aftagere. Derfor kan det også problematiseres, at teknologiforståelse italesættes som en uniform faglighed, der har lige relevans for alle typer af uddannelser. Her er det vores vurdering, at forståelse af (digital) teknologi må afhænge af den uddannelsesspecifikke kontekst og de overordnede intentioner, der er med forskellige uddannelsestyper på langs og på tværs i systemet.

Endelig skal det nævnes, at vi i artiklen her har haft 
fokus på den intenderede praksis, som den er beskrevet i

læreplanen. Hvordan faget reelt udmøntes, og dermed hvordan erhvervsuddannelseslærerne transformerer fagets læreplan til noget, der giver mening i undervisningen og for eleverne, kan analyserne ikke sige noget om. Det synes derfor også nærliggende, at fremtidig forskning netop bør rette blikket mod praksis ude på skolerne og også gerne i det væsentlige samspil med praktikstederne, således at der kan opnås en dybere forståelse af undervisningsfaget Erhvervsinformatik og den tilhørende forståelse af teknologi. Til dette hører også fokus på de organisatoriske og ledelsesmæssige rammer samt de fagfaglige og erhvervspædagogiske-didaktiske forudsætninger lærerne har for at kunne undervise i faget.

\section{Referencer}

Andersen, B. (2021). Personlig kommunikation med STUKs fagkonsulent.

Basballe, D., Caspersen, M., Hansen, B. L., Hjort, M., Iversen, O. S. \& Kanstrup, K. H. (2021). Gap-analyse af teknologiforståelse i det danske uddannelsessystem fra grundskole til ungdomsuddannelser. Danske Professionshøjskoler og Danske Universiteter.

Bekendtgørelse af lov om erhvervsuddannelser (LBK nr. 1395 af 28/og/2020). Lokaliseret på https://www.retsinformation.dk/eli/lta/2020/1395

Bekendtgørelse om erhvervsuddannelser (BEK nr. 1619 af 27/12/2019). Lokaliseret på https://www.retsinformation.dk/eli/lta/2019/1619

Bekendtgørelse om grundfag, erhvervsfag, erhvervsrettet andetsprogsdansk og kombinationsfag i erhvervsuddannelserne og om adgangskurser til erhvervsuddannelserne (BEK nr. 692 af 26/05/2020). Lokaliseret på https://www. retsinformation.dk/eli/lta/202o/692\#idf6d74b83-316c-491a-871c-3904eb62c38o

Bekendtgørelse om grundfag, erhvervsfag, erhvervsrettet andetsprogsdansk og kombinationsfag i erhvervsuddannelserne og om adgangskurser til erhvervsuddannelserne (Historisk) (BEK nr. 37 af 15/o1/2020). Lokaliseret på https://www. retsinformation.dk/eli/lta/2020/37

Børne- og Undervisningsministeriet. (2021). Om erhvervsuddannelser. BUVM. https://www.uvm.dk/erhvervsuddannelser

Caspersen, M. E. (2018). Teaching Programming. I: S. Sentance, E. Barendsen \& C. Schulte (red.), Computer Science Education: Perspectives on Teaching and Learning (s. 109-130). Bloomsbury Publishing.

Caspersen, M. E. (2017). Computationel Thinking. I: J. Dolin, G. H. Ingerslev \& H. S. Jørgensen (red.), Gymnasiepoedagogik - en grundbog (3. udg., s. 470-477). 
Caspersen, M. E. \& Nowack, P. (2013). Computational Thinking and Practice - A Generic Approach to Computing in Danish High Schools. Proceedings of the Fifteenth Australasian Computing Education Conference (ACE20139, Adelaide, Australia. Lokaliseret den 6.12.2021 på: https://citeseerx.ist.psu.edu/viewdoc/ download?doi=10.1.1.710.7635\&rep=rep1\&type $=$ pdf

Chenail, R. J. (2012). Conducting Qualitative Data Analysis: Reading Line-by-Line, but Analyzing by Meaningful Qualitative Units. The Qualitative Report, 17(1), 266269. DOI:10.46743/2160-3715/2012.1817

Cunningham, C. M. \& Kelly, G. J. (2017). Epistemic practices of engineering for education. Science Education, 101(3), 486-505. DOI:10.1002/sce.21271

Dohn, N. B. \& Hansen, J. J. (2016). Didaktik, design og digitalisering. Samfundslitteratur.

EMU (2021). Proesentation af arbejdsgruppen for udvikling affaget. Lokaliseret den 6.12.2021 på: https://emu.dk/eud/erhvervsinformatik/introduktion-til-faget/ praesentation-af-arbejdsgruppen-udvikling-af-faget? $\mathrm{b}=\mathrm{t} 437-\mathrm{t} 2837-\mathrm{t} 284 \mathrm{O}$

Goodlad, J. I., Klein, M. F. \& Tye, K. A. (1979). The domains of curriculum and their study. I: J. I. Goodlad, (red.), Curriculum inquiry: The Study of Curriculum Practice, (s. 43-76). McGraw-Hill.

Gundem, B. B. (1996). Core curriculum - cultural heritage - literacy: Recent perspectives and trends in Norwegian education. I: E. Marum (red.), Children and books in the modern world: An international perspective on literacy, (s. 55-71). Falmer Press.

Hansen, J. J. (2021). Teknologiforståelsesdidaktik: problemløsning, empowerment, eksistens, udfordring og innovation. I: N. Dohn, R. Mitchell \& R. Chongtay (red.), Computational thinking. Teoretiske, empiriske og didaktiske perspektiver (s. 235263). Samfundslitteratur.

Hansen, J. J. \& Karim, A. S. (2020). Alt drejer sig om it. Erhvervsskoleloereres tilgang til it. Syddansk Universitet \& Center for It i undervisningen.

Hansen, J. J. (2012). Fagdidaktiske diskurser: fagdidaktik som videnskab, som politisk diskurs og som praksisvejledning. I: E. Krogh \& F. V. Nielsen (red.), Sammenlignende fagdidaktik 2. Cursiv (9), 225-234.

Hiim, H. \& Hippe, E. (2014). Didaktik for fag-og professionsloerere. Gyldendal.

Hopmann, S., Künzli, R. \& Wisbech Jacobsen, B. (1995). Læseplansarbejdets muligheder og Begrænsninger. Et grundrids af en læseplansteori. I: K. Snack (red.), Loeseplansstudier 3 (s. 339-370). Danmarks Lærerhøjskole.

Imsen, G. (2013). Lcererens verden - indføring i almen didaktik (5. udg.). Gyldendal.

Iversen, O. S., Dindler, C. \& Smith, R. S. (2019). En designtilgang til teknologiforståelse. Dafolo.

Jakobsen, K. H. \& Lausch, B. (2014). Unges identitetsdannelse i EUD. I: T. Størner \& K. H. Sørensen (red.), Elever i erhvervsuddannelserne (s. 145-157). Munksgaard.

Jank, W. \& Meyer, H. (2012). Didaktiske modeller. Grundbog i didaktik. Gyldendal.

Jørgensen, C. H. (2012). Fagligheden i erhvervspædagogikken. I: J. A. Hansen \& T. Størner (red.), I lag med erhvervspoedagogikken (s. 19-27). Erhvervsskolernes Forlag. 
Jørgensen, C. H. (2009). Fag mellem arbejde, organisation og uddannelse: har fagene fremtiden bag sig? Tidsskrift for arbejdsliv, 11(3), s. 13-31. DOI:10.7146/tfa. v11i3.108819

Krogh, E., Qvortup, A. \& Christensen, T. S. (2018). Almen didaktik og fagdidaktik. Frydenlund.

Louw, A. V., Gimmler, A. \& Albrechtsen, T. R. S. (2020). Program om karakterdannelse på erhvervsuddannelserne. Opsamling på forundersøgelse - januar 2020 (1.udg.). Aalborg Universitet.

Lund, B. (red.) (2008). Portfolio i et loerings- og uddannelsesperspektiv. Aalborg Universitetsforlag.

Lundstrøm, A. M. (red.) (2020): Fra Kierkegaard til koder: Computational Thinking i gymnasiet. Systime Academic.

Nielsen, K. (2012). Almenpædagogik og erhvervspædagogik. I: J. A. Hansen \& T. Størner (red.), I lag med erhvervspœedagogikken (s. 29-33). Erhvervsskolernes Forlag.

Nielsen, F.V. (2004). Fagdidaktikkens kernefaglighed. I: K. Schnack (red.), Didaktik på kryds og tvcers (s. 25-45). Danmarks Pædagogiske Universitet.

Nielsen, F. V. (2012). Fagdidaktik som integrativt relationsfelt. I: E. Krogh \& F. V. Nielsen (red.), Sammenlignende fagdidaktik 2. Cursiv (9), 11-32.

Petersen, C. K. (2017). Potentiale og realiserbarhed i forsøgslæreplanen for Informationsteknologi C og B i gymnasiet. Learning Tech - Tidsskrift for loeremidler, didaktik og teknologi, (2), 57-84. DOI:10.714,6/lt.v2i1.107730

Regeringen (2018). Aftale mellem regeringen, Socialdemokratiet, Dansk Folkeprati, Radikale Venstre og Socialistisk Folkeparti om Fra folkeskole til faglcerterhvervsuddannelser til fremtiden. Lokaliseret på https://www.regeringen.dk/ media/5958/fra-folkeskole-til-faglaert-erhvervsuddannelser-til-fremtiden.pdf

Undervisningsministeriet (2018). National naturvidenskabsstrategi. UVM. Lokaliseret på https://www.uvm.dk/publikationer/folkeskolen/2018-nationalnaturvidenskabsstrategi

Riis, M., Rasmussen, C. L. \& Brodersen, A. (2019). Skitse til en grcensekrydsningsdidaktik i erhvervsuddannelser: Med fokus på muligheder for at skabe samspil og sammenhoeng gennem brug af informations-og kommunikationsteknologi. Københavns Professionshøjskole.

Schleiermacher, F. (1826/1957). Pädagogische Schriften. I: W. Flitner, T. Schulze \& E. Weniger. Die Vorlesungen aus dem Jahre 1826. Helmut Küpper.

Schubert, W. H. (2008). Curriculum Inquiry. I: F. M. Connelly, M. F. He \& J. Phillion (red.), The SAGE Handbook of Curriculum and Instruction (s. 399-419). Los Angeles: Sage Publications, 2008. pp. 399-419. DOI:10.4135/9781412976572.n19

Styrelsen for Undervisning og Kvalitet (2019). Vejledning til Grundfagsbekendtgørelse Erhvervsinformatik. STUK.

Svejgaard, K. \& Størner, T. (2010). Fag i erhvervsuddannelse. I: T. Størner \& J. A. Hansen (red.), Erhvervspcedagogik - mål, temaer og vilkår i eud's verden (2. udg., s. 19-25). Erhvervsskolernes Forlag.

Taba, H. (1962). Curriculum development: Theory and practice. Harcourt, Brace \& World. 
Van den Akker, J. (2004). Curriculum perspectives: An introduction. I: J. Van den Akker, W. Kuiper \& U. Hameyer, Curriculum landscapes and trends (s. 1-10). Springer.

Von Oettingen, A. (2016). Almendidaktik - mellem normativitet og evidens. Hans Reitzels Forlag.

Wagner, M., Iversen, O. S. \& Caspersen, M.E. (2020). Teknologiforståelsens rationale: På vej mod computationel empowerment i den danske grundskole. Unge Poedagoger. Tema: Teknologiforståelse på skemaet. UP (1), s. 6-14. 